\title{
Local Finance: Financial Resources Problem in Thailand
}

\author{
Darunee Pumkaew* \\ Faculty of Political Science, Ubon Ratchathani University \\ Warin Chamrap, Ubon Ratchathani Thailand 34190
}

Submitted: 19 April 2019; Accepted: 24 August 2019; Published: 01 December 2019

\begin{abstract}
This study examines local government revenue in the 2016 fiscal year. The study makes use of local budget allocation documents to analyse problems with local public finance from the Department of Local Administration and employs data collected from four groups, namely government officials, experts, local politicians, and local government officials. This study reveals several findings. First, revenue structure of local government does not reflect self-reliance and fiscal autonomy. Instead the revenue of all types of local administrative organizations (LAOs) rely mostly on grants rather than on their self-collected revenues. Second, local administration organizations' revenue between regions is unequal. LAOs in the Northeastern region show the lowest revenues per head from all revenue sources, and grant allocation is not academic-based. The fact that the Northeastern revenue and tax collection is lower than other regions, and that this region is allocated the smallest and fewest grants by the government, is evidence of this. Fourth, finance laws, especially regarding local finance, are outdated. There is no specific legislation on the identification of revenue sources of local administrative organizations, nor is there legislation on the regulation and practice of seeking new revenue sources for these organizations. And fifth, local administrative organizations are incapable of improving the local financial system that includes financial management, staff, and taxpayers.
\end{abstract}

Keywords: Local Public Finance, Fiscal Decentralization

How to Cite: Pumkaew, D. (2019) Local Finance: Financial Resources Problem in Thailand. JPPUMA: Jurnal Ilmu Pemerintahan dan Sosial Politik UMA (Journal of Governance and Political Social UMA), 7 (2) (2019), 7 (2): 148-159.

*Corresponding author:

E-mail: pk_darunee@hotmail.com
ISSN 2549-1660 (Print)

ISSN 2550-1305 (Online) 


\section{INTRODUCTION}

Decentralization has been a policy promoted in Thailand since 1997. The Constitution of Thailand B.E. 2540 (C.E. 1997) established elements of a decentralized system governance and required the central government to transfer certain powers to local governments. One important element of decentralization was to empower the fiscal capacity of local governments to provide public services. However, while the intention of fiscal decentralization is to promote fiscal autonomy, and promote greater self-governance at the local level, significant inefficiencies exist in revenue resources of local governments. The share of local government revenue relative to the total central government revenue is still lower than the amount set by law. The 2nd Determining Plans and Process of Decentralization to Local Government Organization Act, B.E. 2549 (2006) allows local administrative organizations (LAO) to earn revenue of at least 25 percent of the government's net income. This earning implies local governments will receive a minimum of 35 percent of growing revenue in proportion to the government's net revenue.

Yet, the revenue of the local government organizations remained low over the past decade.

\begin{tabular}{|c|c|c|c|c|c|c|c|c|}
\hline \multirow{2}{*}{ Types of LAO revenue } & \multicolumn{8}{|l|}{ Year } \\
\hline & 2014 & $\%$ & 2015 & $\%$ & 2016 & $\%$ & 2017 & $\%$ \\
\hline 1.Local own revenue & 1564.06 & 9.04 & 1707.16 & 9.51 & 1944.44 & 10.67 & 3111.11 & 16.28 \\
\hline $\begin{array}{l}\text { 2. Surcharge tax } \\
\text { revenue }\end{array}$ & 5661.63 & 32.74 & 6061.72 & 33.76 & 6081.66 & 33.36 & 6077.77 & 31.81 \\
\hline 3. Shared tax revenue & 3027.77 & 17.51 & 3027.77 & 16.86 & 3027.77 & 16.61 & 3083.33 & 16.14 \\
\hline 4. Grant revenue & 7041.66 & 40.71 & 7157.32 & 39.86 & 7174.94 & 39.36 & 6835.87 & 35.77 \\
\hline Total revenue & 17295.14 & 100 & 17953.99 & 100 & 18228.83 & 100 & 19108.10 & 100 \\
\hline $\begin{array}{ll}\begin{array}{l}\text { Government } \\
\text { revenue }\end{array} & \text { net } \\
\end{array}$ & 63194.44 & & 64583.33 & & 64722.22 & & 65083.33 & \\
\hline $\begin{array}{lr}\begin{array}{l}\text { Proportion of } \\
\text { revenue }\end{array} \\
\text { government } \\
\text { revenue (Percent) }\end{array}$ & & 27.37 & & 27.8 & & 28.16 & & 29.36 \\
\hline
\end{tabular}

Overall, local revenue in Thailand increased from around 10 percent of total government revenue in 1999 to 29.36 percent in 2017, with local administrative organizations (LAO) receiving 19,108.10 million USD $^{* *}(687,891.61$ million baht), against the central government's net income of $65,083.33$ million USD $(2,343,000$ million baht) (Table 1). Presently, LAOs experience the revenue scarcity to carry out such services for people. LAOs' solution is to depend on the

\footnotetext{
** 1 USD = 36 Baht (Rate exchange in 2016)
}

government's budget. In 2016, LAOs' revenue reached 1944.44 million USD (70,000 million baht) or only 10.7 percent of total local revenues (Table 1). The growing dependence on the central government can negatively influence LAOs' development, meaning that LAOs will be hindered in determining their own local development strategies.

Intergovernmental grants play a significant role in financing revenue for local governments. Grant revenues are intergovernmental transfers, money that local government receive from central government. Intergovernmental grants are dominant revenue for local 
government. The highest grant was 46 percent of local revenue in fiscal year 2001. The amount of grant was 7041 million USD or 40.71 percent in 2014 , and declined to 6835 million USD or 35.77 percent in 2017 (see Table 1). Although the proportion of intergovernmental transfers has decreased, grants are larger percentage of revenue than any other local revenue items.

Public services have encountered obstacles to local finance management. Increasing local revenue is a significant challenge facing the central and local governments. Therefore, this paper aims to evaluate local finance circumstances by analysing the revenue in the fiscal year 2016 and examining the attempts by LAOs in Thailand to achieve greater financial autonomy and self-reliance, existing financial distribution among regions and types of local government organization, and local revenue's problems. Additionally, this paper offers recommendations to help improve local government revenue base, as well as public service delivery and local development.

\section{Concepts and Theories of Fiscal Decentralization}

Fiscal decentralization is the transfer of revenue assignment and expenditure responsibility to lower levels of government. It changes the alignment of fiscal authority and expenditure assignment to different levels of government. In terms of revenue assignment, the two major sources for financing the expenditure of local government are local taxes and intergovernmental transfers (Uchimaru 2012). Local taxes for financing local expenditure is key to allowing local government to set its own expenditure and revenue goals and to ensure it is allocated efficiently. Bird and Vaillancourt (2006) suggest that there are two basic principles for assigning revenue to local government. First, local revenue should be sufficient to enable at least the richest subnational governments to finance all locally provided services that primarily benefit local residents. Second, to the extent possible, subnational revenues should be collected only from local residents and should preferably be related to the benefits they receive from local services. Meanwhile Bird (2006) suggests that local taxes should clearly impose fiscal responsibility at the margin on local government by allowing them to establish their own tax rates with respect to at least some major taxes. However, MartinezVazquez, McLure \& Vaillancourt (2006) argue that if fiscal decentralization is to be reality, local governments must control their own sources of revenue. If subnational governments lack independent sources of revenue, they cannot enjoy fiscal autonomy because they may be under the financial of central government. In terms of intergovernmental transfers, the intergovernmental transfer is emphasized for equity and maintain the national standards for public services across the country. If local governments lack the less capacity to finance services at an adequate level, or there are externalities with regards to services or regional economic disparities, then intergovernmental transfers are need to ensure equitable services across regions (Bird and Vaillancourt, 2006).

The appropriate budgetary empowerment contributes to autonomy of local government and the potential for decentralization. At least four pillars should be considered to ensure successful budgetary decentralization. Firstly, fiscal autonomy, LAOs should develop their revenue collection and budgeting systems based on local needs. Fiscal decentralization has three components to it; revenue, expenditure, and budget (Beer-Toth, 2009). Regarding revenue, local organizations should fully exercise 
their power to tax and collect revenue. Doing so allows LAOs to gain greater spending autonomy and reduce their reliance on intergovernmental grants. Receiving grants represents continued central government control over local organization expenditure. In other words, LAO fiscal management will reflect the government's requirements and policy goals, rather than the needs of local people. In terms of expenditure, local organizations can design spending patterns appropriate to service provision and asset management. The expenditure autonomy is the right and the ability of local government to determine public property and funds to meet the demand of local constituency, and the freedom to decide the how public service shall be produced. On budgeting, local organizations should plan budgets according to the local needs under the government's supervision, instead of instructions from government on what people need. If local revenue is insufficient, local governments should be authorized to seek loans when appropriate.

Secondly, fiscal self-reliance; LAOs should earn sufficient revenue through the local tax base to meet local demands for public service functions as regulated by law. Thirdly, fiscal accountability is crucial for all local administration bodies, to balance revenue and expenditure while equalizing local benefits and financial burdens.

Lastly, fiscal equality is also important to ensure that there are neither significant fiscal disparities, nor fiscal inequalities between LAOs. As for fiscal capacity, different local governments have various economic bases which effects their ability to generate revenue. If the horizontal fiscal imbalance situation between local governments is not improved, it may lead to migration. In other words, people migrate out of jurisdictions that give them less satisfactory public services to places with public services that better suit their needs (Tiebout 1956). These pillars are indispensable to secure LAO's revenue sources and autonomy from the central government, as well as the overall economy and economic development of the country.

\section{RESEARCH METHODS}

Government documents and interviews with officials were two primary sources of data. This study analysed documents concerning budget allocation to LAOs, including records from the Department of Local Administration in the fiscal year 2016. Interviews, as part of the field research, were conducted with four target groups, namely, government staff, experts, local politicians, and local government staff. Data collection took place between November 2016 and March 2017.

The paper analyses local revenue streams in the Fiscal Year 2016 and finds that LAOs received $28.16 \%$ of their total income of 656,238 million baht whereas the government's total revenue was 64,722.22 million USD (Table 1). Thailand has 30 city municipalities with 2.7 million people, $\quad 178$ town municipalities with 4.5 million people, 2,233 sub-district municipalities with 16.3 million people and 5,334 sub-district administrative organizations with 35.7 million people (Table 2). Among revenue sources, grants are the primary source of revenue for all types of local administrative organizations. Selfcollected revenue, such as through taxation, accounted for the smallest proportion of their total budget. 
Table 2. Local own revenue, shared tax revenue, grant revenue, total revenue in fiscal year 2016. Unit: Million USD.

\begin{tabular}{|c|c|c|c|c|c|c|c|}
\hline Types of LAO & $\mathrm{N}$ & $\begin{array}{l}\text { Population } \\
\text { (person) }\end{array}$ & $\begin{array}{l}\text { Area } \\
\left(\mathrm{km}^{2}\right)\end{array}$ & $\begin{array}{l}\text { Local } \\
\text { own } \\
\text { revenue }\end{array}$ & $\begin{array}{l}\text { Shared } \\
\text { tax } \\
\text { revenue }\end{array}$ & $\begin{array}{l}\text { Grant } \\
\text { revenue }\end{array}$ & $\begin{array}{l}\text { Total } \\
\text { revenue }\end{array}$ \\
\hline City municipality & 30 & 2788034 & 1441.58 & 168.15 & 341.08 & 342.33 & 851.56 \\
\hline Town municipality & 178 & 4570818 & 4654.22 & 190.95 & 523.45 & 600.45 & 1314.85 \\
\hline Sub-district municipality & 2233 & 16300000 & 100724.70 & 280.19 & 1551.05 & 1646.81 & 3478.05 \\
\hline $\begin{array}{l}\text { Sub-district administrative } \\
\text { organization }\end{array}$ & 5334 & 35700000 & 400190.30 & 318.90 & 2734.95 & 3085.86 & $\begin{array}{l}6139.70 \\
11784.16\end{array}$ \\
\hline Total & 7775 & 59300000 & 507010.80 & 958.19 & 5150.53 & 5675.45 & \\
\hline
\end{tabular}

From their self-collected revenue, sub-district administrative organization earn approximately 8.75 USD per capita, around six times smaller than city municipalities. Town municipalities receive the highest grant allocation of 153.36 USD per head (Table 3). The lowest allocation 90 USD per head belongs to sub-district administrative organizations. The comparison between revenue per head from all revenue sources reveals a massive reliance on grants among all types of LAOs.

Table 3. Local own revenue, shared tax revenue, grant revenue, total revenue in fiscal year 2016

\begin{tabular}{lllllll}
\hline Types of LAO & $\mathrm{N}$ & $\begin{array}{l}\text { Population } \\
\text { (person) }\end{array}$ & $\begin{array}{l}\text { Local own } \\
\text { revenue }\end{array}$ & $\begin{array}{l}\text { Shared tax } \\
\text { revenue }\end{array}$ & $\begin{array}{l}\text { Grant } \\
\text { revenue }\end{array}$ & $\begin{array}{l}\text { Total } \\
\text { revenue }\end{array}$ \\
\hline $\begin{array}{l}\text { City municipality } \\
\text { Town municipality }\end{array}$ & 30 & 2788034 & 60.13 & 122.05 & 131.68 & 313.86 \\
$\begin{array}{l}\text { Sub-district municipality } \\
\text { Sub-district administrative }\end{array}$ & 178 & 4570818 & 40.34 & 121.36 & 153.37 & 315.07 \\
$\begin{array}{l}\text { organization } \\
\text { Total }\end{array}$ & 5334 & 16300000 & 17.00 & 110.02 & 115.16 & 242.18 \\
\hline & 7775 & 59300000 & 12.04 & 93.06 & 98.86 & 203.96 \\
\hline
\end{tabular}

Source: Department of Local Administration (2017)

Unit: USD per capita The analysis of LAO revenue in all regions indicates that LAOs' revenue is different among the region. In principle, local government with smaller sources of revenue should receive higher grant amounts from the central government to ensure services are equal compared to other areas regions (Bird and Vaillancourt, 2006, p 3). However, this does not happen in practice. The lowest revenue per head-at only 6.25 USD-from all revenue sources is in the Northeastern Region of country. This revenue is six times smaller than the self-collected revenue earned by Bangkok vicinities, which earns 79.86 USD per head from the shared tax revenue and 94.25 USD per head from the grant (Table
4). In addition to their self-collected revenue and shared tax revenue of the Northeastern Region being lower than other regions, this region also has less grants allocated to it than others. 
JPPUMA: Jurnal Ilmu Pemerintahan dan Sosial Politik UMA (Journal of Governance and Political Social UMA),

7(2) (2019): 148-159

Table 4. Local government's revenue in fiscal year 2016, by region

\begin{tabular}{llllllll}
\hline Region & & & & \multicolumn{4}{c}{ Unit: USD per capita } \\
\hline Northeast & $\mathrm{N}$ & Population & Area $\left(\mathrm{km}^{2}\right)$ & $\begin{array}{l}\text { Local own } \\
\text { revenue }\end{array}$ & $\begin{array}{l}\text { Shared tax } \\
\text { revenue }\end{array}$ & $\begin{array}{l}\text { Grant } \\
\text { revenue }\end{array}$ & $\begin{array}{l}\text { Total } \\
\text { revenue }\end{array}$ \\
North & 2947 & 21800000 & 166043 & 6.27 & 79.86 & 94.27 & 180.40 \\
South & 1676 & 11800000 & 166887 & 8.50 & 94.21 & 108.09 & 210.80 \\
East & 1176 & 9254431 & 71867 & 14.91 & 93.20 & 104.47 & 212.58 \\
West & 575 & 4743261 & 36952 & 26.32 & 113.79 & 94.88 & 235.00 \\
Central & 537 & 3727562 & 42809 & 11.43 & 99.91 & 95.84 & 207.18 \\
Bangkok vicinities & 554 & 3010505 & 16346 & 18.92 & 114.75 & 100.21 & 233.89 \\
Total & 310 & 4968463 & 6107 & 37.39 & 122.80 & 81.39 & 241.58 \\
\hline Sotal & 7775 & 59300000 & 507011 & 12.04 & 93.06 & 98.86 & 203.96 \\
\hline
\end{tabular}

Source: Department of Local Administration (2017)

\section{RESULT AND DISCUSION}

Law-related Problems and Local

\section{Revenue}

The laws establishing LAOs also prescribe their sources of local revenue. These include the Provincial Administrative Organization Act, B.E. 2540 (Section 73), the Municipal Act, B.E. 2496 (Section 66), and the Sub-district Council and Sub-district Administrative Organization Act, B.E. 2537 (Section 82); the Determining Plans and Process of Decentralization Act, as well as other specific laws on local revenue sources. The Provincial Administrative Organization Act and the Municipality Act allow PAO and municipality may have their revenue resources from 1) taxation as prescribed by law 2) fees, license fees and fines 3) their own assets 4) their own public utilities, 5) their commerce 6) bonds or loans 7) loans from ministries, department as approved by the Minister 8) subsidies from government 9) donations 10) and other sources of revenue as provided by law to belong to the $\mathrm{PAO}$, belong to municipality. Meanwhile, the Sub-district Administrative Organization is also have revenue as well as PAO and municipality but accept bonds and loans.

Specific laws supporting local revenue sources, as detailed in the law on the set-up of LAOs, allow localities to collect revenue on their own. The mentioned laws embrace the signboard tax under the Signboard Tax Act, the local development tax under the Local Development Tax Act, and the building and land tax under the Building and Land Tax Act. According to in-depth interviews with experts, local politicians, and local government officials (2016), the section below presents a summary of the problems which the laws mentioned above produce.

Amendments to local tax laws rarely reflect changing social contexts. Locally levied taxes are made possible through specific laws. However some of these laws have not been amended since their enactment decades ago. For instance, the Signboard Tax Act, B.E. 2510 for local signboard taxation, the Local Development Tax Act, B.E. 2508 for local development taxation and the Building and Land Tax Act, B.E 2475 for building and land taxation have remained unchanged.

New sources of revenue encounter obstacles in terms of regulation and implementation. For instance, the Council of State interprets municipal enterprises as an affair in conflict with the law prohibiting local organizations from operating them, besides limitations over investments and profit-making. The interpretation changes the enterprise into a competitor with private businesses. If any LAO plans to operate a counter service business to generate revenue, the plan will not be achievable. On the other hand, a 
large LAO can operate an electric power plant in the absence of legal permission. This evidence shows the foreseen impossibility for new creativities of local revenue. Local organizations will be at risk of violating laws which could result in the persecution of their executives. However, if strongly insisting on new revenue generation, the executives have to strive for it, perhaps through formal inquiries to all concerned authorities and waiting for their delayed answers.

Most local collected revenues assigned by law are narrow-based taxes, such as the building and land tax, the local development tax, the signboard tax, and the animal slaughtering tax. As a consequence, the percentage of locally collected revenue amounts to the smallest revenue source, making just 10 percent of LAO total revenue. This significantly affects local autonomy. Nationally-imposed fixed-rate taxes hinder LAO ability to adapt to changes to the economy and prevents localities from freely deciding local tax items.

Law enforcement is problematic. By law, local tax revenue collection is feasible through the use of fines and penalties for taxpayers failing to meet their required obligations. In practice, however, law enforcement treats taxpayers differently. An example case concerns the building and land tax which, as permitted by law, local governments are authorized to enforce measures against those failing to file taxes. The measures are made up of: issuance of warning letters to taxpayers to provide statements or submit documents; issuance of warning letters to make payment; issuance of orders for taxpayers to negotiate a deal; and failing that, the seizure, attachment or selling properties by auction. However, local governments find it difficult to enforce the last measure. There are no clear implementation guidelines and a significant degree of complexity. Also, if it is enforced, the local leader's electoral base will be negatively affected. It is suggested that law amendments should be prioritized to ensure the effective implementation and enforcement of tax liabilities for all taxpayers at the local level.

\section{LAO Capacity-related issues and fiscal improvements}

Local administration taxation does not have a proactive approach. LAOs commonly tax by requiring all taxpayers to inform them with a list of their assets. The Department of Local Administration has already introduced a tax and property mapping software called LTAX 3000, and a GIS application called LTAX GIS. The program is aimed at increasing convenience, processing speeds, and validity for taxation process. At the operational level, however, such aims have not been met as the mapping process depends upon the LAOs workforce, budget, and available time. A lack of checking and monitoring of taxation is common in localities and advanced technologies are not used for tax payment services (Local government officials, Interview, 2016). The technological issues are explained by budget insufficiencies in some local areas, with most budgets directing funds towards other development projects. On the whole, local taxation capacity is low. The reason for local authorities' loss of interest in taxation improvement partially derives from the revenue structure that heavily relies on tax revenues and intergovernmental grants from the government.

Human resources are also a challenge. Local staff are needed to build effective and efficient taxation capacity of LAOs (Local government officials, Interview, 2016). Furthermore, LAO leaders often believe that it is not in their political interest to implement efficient taxation schemes. They fear losing their electoral support. In fact, some LAOs even give land tax exemptions or adopt a low- 
rate tax to maintain their leader's political position.

Taxpayers try to either pay the minimum rate of tax or avoid it entirely. Many use their political connections to receive tax deductions or find gaps in the taxation system to avoid paying higher taxes. Also, most people appear to fundamentally misunderstand the role of local government and are, therefore, unwilling to pay local taxes.

\section{LA0s' Budget Allocation Issues: Intergovernmental Grants}

The objective of intergovernmental grant allocation is to narrow fiscal gaps between LAOs and to achieve horizontal equality. Decentralization has transferred a range of functions and revenues to LAOs. But the demands, service delivery costs, and revenue-raising capacity vary by locality. In many cases, some districts do not perform their functions at full capacity if they rely on tax-revenue alone, meaning that fiscal disparities or gaps are inevitable. This is why intergovernmental grants are the primary tool to equalize fiscal capacity between localities. These grants ensure a balance between revenues and expenditure, which are assigned to local governments, and build fiscal equality between localities.

However, grant allocations that are not equitably distributed will run into at least three problems (Martinez-Vazquez \&Boex 2001). Firstly, some LAOs suffer revenue inadequacies by attempting to perform functions at national-standards. Subsequently, different areas may provide different standards for the same public service. Secondly, horizontal fiscal disparities remain unchanged, particularly among LAOs with greater fiscal needs and smaller budgetary capacity. And lastly, intergovernmental transfers cannot act as an influential tool in achieving policies at national level.

The Determining Plans and Process of Decentralization Act, B.E. 2542 authorizes the Decentralization to Local Government Organization Committee with decisionmaking powers over grant allocation, including criteria and objectives for distribution. This authorization includes the access of standard public services at the local level, reducing gaps between localities with diversified fiscal status, performing specific tasks based on government policy, and reaching solutions to problems which are beyond a LAO's budgetary capacity. To genuinely accomplish the objectives of grant allocation, the allocation criteria and methods should be designed to prevent intergovernmental grants from merely being used as a sources of revenue for most LAOs, but instead to become a tool to achieve fiscal equalization. From 1999 onwards, the Thai government has allocated intergovernmental grants to LAOs, making the fiscal status of LAOs deeply reliant on financial support from the government. Indeed, over 40 percent revenue for LAOs comes from intergovernmental grants.

Currently, revenue allocation does not achieve the goal of local-government fiscal equity. The set of criteria governing allocation appears to be simple and grounded on population, per-capita and area bases. But while, allocation adjustment methods exist, obstacles exist. For instance, local areas with nonregistered populations create barriers to revenue capacity and expenditure for local administration and public services. As such, allocated grants are not a reliable source of revenue for many local communities. Allocation criteria, in general, are out of touch with current and future situations (Academics, Interview, 2016).

Inadequate statistics at the local level and the lack of coverage of numerous indicators hinders effective grant allocation. Records and historical data are either scarce or not organized in a standardized format. Recorded data is 
often incomplete, dispersed, and inconsistent. This is largely due to the fact that local governments lack the capacity to effectively record data. There are no local statistics offices or statisticians in charge of the local statistical data system. Local data collection is rarely carried out because of budgetary, staffing, operational or coordination limitations. Data sharing among local units is incredibly rare, and it is therefore impossible to establish a central data hub for search and analysis. The final explanation deals with data records barely being available in LAOs. In some cases, the data does exist at all or is inconsistently recorded, perhaps owing to occasional requests for particular data from the Department of Local Administration.

Uncertainty of allocated grant, grant uncertainty makes it difficult for local governments to predict exact grant amounts. Customarily, intergovernmental grants may be decreased due to national and global economic conditions. Grant allocations may also be constrained by new government policy. In 2016-2017, grants allocated to LAOs were reduced as the government sought to allocate grants to village headmen, rather than through LAOs.

The exact sources of grants are not assigned by law, and grant allocation criteria is modified every year. The unpredictable nature of grant allocation makes it difficult for LAOs to plan ahead, and as a consequence, constrains local development plans.

Delayed allocated grants, this pertains to the general grants defined by purpose, for example for the provision of school milk, childcare facilities, old-age allowances, disability living allowances, and so forth. The long and slow allocation process affects scheduled development project activities directed by LAOs, frequently forcing them to use their reserve finances until the grants are received. As a consequence, local authorities are required to explain the use of the prospective grants to the Office of the Auditor General of Thailand. In many instances, grants are allocated just before the end of the fiscal year, leaving LAOs unable to complete their projects on time.

Specific grants allocated to LAOs have been increasing annually. In 2012 alone, the grant amount jumped up to 50 percent of total intergovernmental grants (Table $6)$. By name, the specific grants are meant for specific purposes or policies set by the government. It is impossible for local governments to exercise discretion or autonomy for grant utilization.

General characteristics of this specific grant allocation is detailed here. Grant allocation is often seen as an outcome of political negotiation among various actors, such as between local and national political players, or between local decisionmakers (Local government officials, Interview, 2016, Local Politicians, Interview, 2017). Notably, before the decision on grant allocation, players on the local side often try to gain grants using political favours, with good connection with politicians and decision makers often benefiting local organizations. On the other side, the central authority may visit LAOs for grant allocation. After talks end with a mutual understanding, grants are given to LAOs. However, the specific grant allocation draws mostly on the negotiation over revenue proportion, exchange of interest and development projects stipulated by the central government, rather than local government. 
JPPUMA: Jurnal Ilmu Pemerintahan dan Sosial Politik UMA (Journal of Governance and Political Social UMA),

7(2) (2019): 148-159

Table 6. General and specific grants allocated to local administrative organizations 2006-2017 Unit: Million USD

\begin{tabular}{llllll}
\hline Fiscal Year & General Grants & Percent & Specific Grants & Percent & Total grants * \\
\hline 2006 & 2740.47 & 89.50 & 321.00 & 10.48 & 3061.47 \\
2007 & 3174.81 & 92.48 & 257.81 & 7.51 & 3432.61 \\
2008 & 3055.47 & 83.91 & 585.47 & 16.08 & 3640.94 \\
2009 & 2891.64 & 77.34 & 846.78 & 22.65 & 3738.43 \\
2010 & 2063.08 & 59.24 & 1419.20 & 39.24 & 3482.31 \\
2011 & 2223.03 & 48.69 & 2341.77 & 51.30 & 4564.80 \\
2012 & 2380.42 & 41.76 & 3319.36 & 58.23 & 5699.78 \\
2013 & 2901.25 & 47.57 & 3196.52 & 52.42 & 6097.77 \\
2014 & 3526.88 & 53.77 & 3031.15 & 46.22 & 6558.02 \\
2015 & 5825.88 & 87.16 & 857.49 & 12.83 & 6683.38 \\
2016 & 5658.26 & 85.89 & 929.37 & 14.10 & 6587.63 \\
2017 & 5759.80 & 93.15 & 423.17 & 6.84 & 6182.96 \\
\hline
\end{tabular}

Source: Office of the Decentralization to the Local Government Organization Committee (2009-2017), National Municipal League of Thailand (2013)

*Total grants allocated to provincial administrative organizations, municipalities, and sub-district administrative organizations through the Department of Local Administration (excluding Bangkok and Pattaya).

The specific grant lies under the budget determined by Members of Parliament (MPs). This way, MPs elected by local people attempts to redeploy grants to their own constituency. MPs may informally exert their influence or give instructions to budget allocation authorities to approve the budget for MPs' constituencies. The approved budget carries a positive relationship with MPs' popularity. Positive consequences also can fall on election campaigners, who successfully make the procurement agreements with government organizations, such as agreements on constructing and dredging canals and waterways.

The use of specific grants are on the rise, particularly for policies initiated by the central government, leaving many LAOs receiving money they can only use for specific purposes, and are unable to use it for other purposes such as service delivery, problem-solving, developments, and improvements, or for anything else required by the local area. Under the government of Mr. Abhisit Vejjajiva and Ms. Yingluck Shinawatra, specific grants were given to LAOs to implement policies such as the old-age allowance, the disability living allowance, the stipend for village health volunteers and the children's school lunch grant.

A serious reassessment of grant allocation procedures must be undertaken to ensure that it is in-line with local functions, authorities, and expenditures, and to realize fiscal equity. A reassessment should take into consideration the development of a local database to support allocation criteria for local fiscal balance. When considering the specific grant utilization, the purpose of usage should be made clear and stringent monitoring and enforcement should be implemented. Without these, corruption and ineffective use of resources would arise (Ahmad \& Craig 1997). Finally, a politically neutral organization or a committee on specific grant allocation should decide grant allocation to avoid political deals.

\section{Problems Concerning Budget Public Budget Participation}

Involving local people in local budgeting is crucial. By participating in the decision-making process, local 
communities can better express their priorities and concerns. Greater engagement from the local community can also make the process more public and accountable. Budgeting can serve public's requirements and facilitate monitoring and transparency mechanisms for all LAO operations. Even so, public budget participation remains inadequate, especially when it comes to budget making. Public participation is limited, with little public engagement on the problems and needs of development projects.

\section{CONCLUSION}

Fiscal decentralization of revenue assignment does not reach fiscal autonomy. The revenue proportion between local government and central government is still less than 30 percent of total central government revenue. In terms of local revenue structure, overall, locally collected revenue does not ensure fiscal self-reliance and as a consequence LAOs lack budgetary autonomy. Indeed, local revenue relies on intergovernmental grants for a substantial part of their budget. Most local governments are only able to generate around 10 percent of their total revenue from local revenue generation. The problem is in large part due to the laws and regulations in place for local finance. The content of many of these laws is outdated and create ambiguities on the assigned revenue sources and the prohibition of new revenue sources. Moreover, the issue reflect concerns LAO's low capacity to improve their fiscal administration, human resources and ensure full and even taxation

In addition, grant distribution does not support revenue equity among LAOs. The less revenue capacity LAO get less amount of grants, because of a weak allocation criteria and political interference, particularly concerning specific grant allocation.
This study recommends that: 1) Grant allocation is reformed to lessen fiscal disparity between LAOs. The reformation is feasible through the academic-based calculation formula. This also means more grants should be allocated to local organizations with smaller revenues. The current situation is that LAOs, like Northern sub-district administrative organizations, which have lower revenues, receive smaller grants than other regions' local organizations with higher revenues. 2) Laws on the revenue of LAOs need to be revised. The revenue sources for each local administrative organization should be clearly defined. At the same time, obsolete laws should be amended to pave the way for organizations to generate new revenues. 3) LAOs should find ways to better employ technologies, improve staff competency and involve local people in the LAOs activities in order increase the effectiveness of revenue collection and revenue use.

\section{REFERENCE}

Fiscal Policy Bureau, Fiscal Policy Office. (2015). Revenue Proportion of Local Administrative Organization. Retrieved 7 January 2017, from the website: http://www.fpo.go.th/fpodoc/การคลังท้องถิ่น \%20FIT\%20D108

$119 /$ สัดส่วนรายได้ขององค์กรปกครองส่วนท้องถิ่น.X lsx

National Municipal League of Thailand (2013). Budget Allocation to Local Administrative Organization. Retrieved 7 January 2017, from the website: http://www.nmt.or.th/DocLib14/2554/ chart_subsidies52.pdf

http://www.nmt.or.th/DocLib14/2555/plan\%20 funding_55.pdf

http://www.nmt.or.th/DocLib14/2553/การจัดสรรง บประมาณแก่ $\% 20$ อปท. $\% 202553 /$ เอกสารเพิ่ม $/ 4$. การจัดสรรรายรับให้\% 20 อปท.pdf

Office of the Decentralization to the Local Government Organization Committee (2009-2017). Allocated Intergovernmental Grant to Local Administrative Organization, Fiscal Year 2009-2017. Retrieved 16 May 2017, from the website: http://www.odloc.go.th/web/?page_id=156 9 
Office of the Decentralization to the Local Government Organization Committee (20002017). Table of Revenue Allocation to Local Administrative Organization Fiscal Year 2009-2017. Retrieved 16 May 2017, from the website: ttp://www.odloc.go.th/web/?page_id=1562

Office of the Decentralization to the Local Government Organization Committee. (2017). Table of Revenue Proportion Comparison, 2006-2017, Retrieved 17 April 2017, from the website: https://drive.google.com/file/d/0B_chJTaN UH8BWFpRSXhabmNSY3c/view

Ahmad E.\& Craig J. (1997). "Intergovernmental Transfer". In Ter-Minassian T. (Eds.), Fiscal Federalism in Theory and Practice, pp.73107. International Monetary Fund.

Beer-Toth K. (2009). Local Financial Autonomy in Theory and Practice: The Impact of Fiscal Decentralization in Hungary, retrieved June 7, 2017, from http://www.unifr.ch/ses/ses2007/uploads/ Beer-TothK

Bird R.M. \& Vaillancourt F. (2006). "Introduction and Summary". In Bird RM. \& Vaillancourt F. (Eds.), Perspectives on Fiscal Federalism, pp.1- 12. Washington: The World Bank.

Bird R.M. (2006). "Local and Regional Revenues: Realities and Prospects". In Bird RM. \&
Vaillancourt F. (Eds.), Perspectives on Fiscal Federalism, pp. 177-196. Washington: The World Bank.

Kitchen H. (2007). "Grants to Small Urban Governments". In Boadway R. \& Shah A. (Eds.), Intergovernmental Fiscal Transfers: Principles and Practice pp.483-510. Washington, D.C.: The World Bank.

Martinez-Vazquez, J. \& Boex, J. (2001). The design of equalization Grants: Theory and

applications, Part one: theory and concepts. Atlanta, GA: The World Bank Institute and the Andrew Young School of Policy Studies, Georgia State University.

Martinez-Vazquez J., McLure C. \& Vaillancourt F. (2006). Revenues and Expenditures in an Intergovernmental Framework. In

Bird R. M. \& Vaillancourt F. (Eds). Perspectives on Fiscal Federalism, pp.15-34. Washington: The World Bank.

Tiebout C.M. (1956). A Pure Theory of Local Expenditures. Journal of Political Economy, 64(5):416-424.

Uchimura H. (2012). "Introduction”. In Uchimaura H.(Eds.). Fiscal Decentralization and Development: Experiences of Three Developing Countries in Southeast Asia. Hampshire: Palgrave Macmillan. 